\title{
Składki na ubezpieczenia emerytalne i rentowe osób sprawujących opiekę nad osobami niepełnosprawnymi
}

\section{Contributions to the old-age pension insurance and disability and survivor's pension insurance for persons taking care of people with disabilities}

Streszczenie. Problem opieki skupia w sobie wiele kwestii socjalnych. Od kwalifikacji prawnej samej opieki, poprzez problematykę sposobów wsparcia, wysokość świadczeń, aż po zakres ochrony opiekunów. Jednym z istotniejszych zagadnień godnym uwagi w problematyce opieki nad osobami niepełnosprawnymi jest obowiązek ubezpieczenia społecznego osób podejmujących się opieki. Publikacja koncentruje się na problematyce opłacania składek. Status ubezpieczeniowy opiekunów jest skomplikowany i niestabilny. Trudność jego oceny wiąże się brakiem ostatecznego kształtu systemu opieki długoterminowej w zdeinstytucjonalizowanych warunkach.

Słowa kluczowe: system ubezpieczeń społecznych; składki na ubezpieczenie emerytalne i ubezpieczenia rentowe; opiekunowie osób niepełnosprawnych. 
Abstract. The care issue brings together a number of social issues. From the legal classification of care, through the problem how to support, the amount of benefits to the scope of protection of caregivers. One of the most noteworthy problems in care for the disabled persons is the duty of providing social insurance for caregivers. The publication focuses on the issue of payment of contributions. Carers' insurance status is complex and unstable. The difficulty of evaluation is related to the lack of the final shape of long-term care system in deinstitutionalized conditions.

Keywords: social insurance system; contributions to the old-age pension insurance and disability and survivor's pension insurance; caregivers of persons with disabilities.

\section{Wprowadzenie}

Problem opieki skupia w sobie wiele kwestii socjalnych. Od kwalifikacji prawnej samej opieki, poprzez problematykę sposobów wsparcia, wysokość świadczeń, aż po zakres ochrony opiekunów. Jednym z istotniejszych zagadnień godnym uwagi w problematyce opieki nad osobami niepełnosprawnymi jest obowiązek ubezpieczenia społecznego osób podejmujących się opieki. Publikacja koncentruje się na problematyce opłacania składek, z tego też powodu nie odnosi się do wszelkich form opieki zawodowej. Biorąc jednak pod uwagę zmienność rozwiązań prawnych w dziedzinie zarówno świadczeń rodzinnych, jak i ubezpieczeń społecznych, a zwłaszcza brak kompleksowego rozwiązania problemu ryzyka opieki długoterminowej, wyjątkowo trudno jest oceniać obowiązek ubezpieczeń emerytalnego i rentowych opiekunów.

Sprawowanie opieki rozumianej jako wykonywanie lub pomoc przy wykonywaniu podstawowych czynności życiowych może być podyktowana różną motywacją. Najczęściej jest to jednak przymus rodzinny i ekonomiczny, który zwykle spada na kobiety. Ustawodawca, obejmując ochroną opiekunów, stara się uwzględniać szerszy kontekst rodziny, sytuację materialną, możliwość wypracowania środków finansowych lub uprawnień do świadczeń z ubezpieczeń społecznych w przypadku osób, których niepełnosprawność powstała w dorosłym życiu. Nie czyni tego jednak w sposób ani społecznie sprawiedliwy, ani racjonalny. Nie omawiając szerzej zakresu 
i form wsparcia opiekunów, podkreślić należy, że zróżnicowanie to pośrednio przekłada się na zakres ochrony ubezpieczeniowej.

Ustawodawca już w przeszłości przewidywał szczególne instrumenty ochrony osób zmuszonych przerwać pracę zarobkową z powodu konieczności sprawowania opieki ${ }^{1}$. Jednym z istotniejszych było prawo do wcześniejszej emerytury ${ }^{2}$. Inne rozwiązania na przestrzeni lat to zaliczanie okresów opieki do okresów zatrudnienia lub traktowanie jako okresów równorzędnych z okresem zatrudnienia ${ }^{3}$. A po wprowadzeniu ustawą rewaloryzacyjną podziału na okresy składkowe i nieskładkowe - zaliczanie niektórych okresów opieki do stażu ubezpieczeniowego jako okresów nieskładkowych, czy możliwość dobrowolnego opłacania składek przez wskazanych opiekunów ${ }^{4}$. Z kolei na etapie reformy emerytalnej pojawił się obowiązek opłacania składek za opiekunów pobierających zasiłek stały, zastąpiony później świadczeniem pielęgnacyjnym5 ${ }^{5}$. Obejmowanie ubezpie-

1 Zob. krótki rys historyczny B. Gudowska [w:] B. Gudowska, J. Strusińska-Żukowska (red.), Ustawa o systemie ubezpieczeń społecznych. Komentarz, Warszawa 2014, s. $142,144-145$.

2 Rozporządzenie Rady Ministrów z dnia 15 maja 1989 r. w sprawie uprawnień do wcześniejszej emerytury pracowników opiekujących się dziećmi wymagającymi stałej opieki (Dz.U. Nr 28, poz. 149 ze zm.).

$3 \quad$ Art. 11 ust. 2 pkt. 9, art. 13 ust. 3 pkt. 1 ustawy z dnia 14 grudnia 1982 r. o zaopatrzeniu emerytalnym pracowników i ich rodzin (Dz.U. Nr 40, poz. 267 ze zm.) według stanu obowiązującego przed uchyleniem ustawy.

$4 \quad$ Art. $4^{2}$ pkt. 2 ustawy z dnia 25 listopada 1986 r. o organizacji i finansowaniu ubezpieczeń społecznych (tekst jedn. Dz.U. z 1989 r., Nr 25, poz. 137 ze zm.). Na podstawie rozporządzenia RM z dnia 29 stycznia 1990 r. w sprawie wysokości i podstawy wymiaru składek na ubezpieczenie społeczne, zgłaszania do ubezpieczenia społecznego oraz rozliczania składek i świadczeń z ubezpieczenia społecznego (tekst jedn. Dz.U. z 1993 r. Nr 68, poz. 330 ze zm.) składka wynosiła 32\% zadeklarowanej przez te osoby kwoty, nie niższej od najniższego wynagrodzenia.

$5 \quad$ Art. 58 ustawy z dnia 28 listopada 2003 r. o świadczeniach rodzinnych (tekst jedn. Dz.U. z 2015 r. poz. 114). Por. wyrok WSA w Gliwicach z dnia 21 lipca 2009 r., IV SA/Gl 930/08 LEX nr 553432: „Skutkiem prawnym art. 58 ust. 1 ustawy z 2003 r. o świadczeniach rodzinnych jest przekształcenie dotychczasowego zasiłku stałego w świadczenie pielęgnacyjne. Z brzmienia tego unormowania, a w szczególności z użytego w nim sformułowania «nabywa prawo» wynika, że omawiana konwersja następuje z mocy prawa, przy czym osoba uprawniona składa wniosek, a organ wydaje stosowną decyzję”. Jednakże osoba zdolna do pracy, lecz niepozostająca w zatrudnieniu ze względu na konieczność sprawowania opieki nad dzieckiem wymagającym stałej pielęgnacji, posiadającym orzeczenie o niepełnosprawności wraz ze wskazaniami konieczności stałej 
czeniami emerytalnym i rentowymi opiekunów nie jest więc rozwiązaniem nowym. Nie jest też rozwiązaniem odosobnionym. Można nawet powiedzieć, że dało asumpt do rozwoju innych tytułów dla osób nieaktywnych zawodowo z powodu realizacji celów doniosłych społecznie.

\section{Tytuły do ubezpieczeń opiekunów w ustawie systemowej}

Obecnie tytuły do obowiązkowego ubezpieczenia emerytalnego i rentowych zawarte są w katalogu art. 6 ustawy o systemie ubezpieczeń społecznych ${ }^{6}$. Ustawa stanowi o obowiązku ubezpieczenia emerytalnego i rentowych opiekunów w dwóch przepisach. Różnią się one w określeniu tytułów do ubezpieczenia. Oba nie wskazują również na wyłączną, samoistną podstawę do objęcia tymi ubezpieczeniami takiej okoliczności, jak rezygnacja lub niepodejmowanie zatrudnienia i sprawowanie opieki nad osobą niepełnosprawną. Bowiem towarzyszyć im musi przesłanka bądź niskiego dochodu w rodzinie, bądź pobierania określonego świadczenia opiekuńczego, które to z kolei powiązane są z wiekiem, w jakim powstała u osoby wymagającej opieki niepełnosprawność, i ewentualnym kryterium dochodowym ${ }^{7}$. W obu wypadkach to w przepisach poza systemem ubezpieczeń społecznych wskazane są podmioty uprawnione czy to do świad-

lub długotrwałej opieki lub pomocy innej osoby w związku ze znacznie ograniczoną możliwością samodzielnej egzystencji i konieczności stałego współudziału na co dzień opiekuna dziecka w procesie jego leczenia, rehabilitacji i edukacji wynikającymi z ustawy o rehabilitacji zawodowej i społecznej oraz zatrudnianiu osób niepełnosprawnych, za które ośrodek pomocy społecznej opłacał składkę na ubezpieczenia społeczne przed dniem 1 stycznia 1999 r., nabywała prawo do emerytury bez względu na wiek, jeżeli w dniu 1 stycznia 1999 r. ukończyła co najmniej 45 lat i ma okres ubezpieczenia (składkowy i nieskładkowy) wynoszący co najmniej 20 lat w przypadku kobiet i 25 lat w przypadku mężczyzn.

$6 \quad$ Ustawa z dnia 13 października 1998 r. o systemie ubezpieczeń społecznych (tekst jedn. Dz.U. z 2015 r., poz. 121).

7 Powstały nowe założenia do świadczeń opiekuńczych uzależniające je w każdym wypadku od kryterium dochodowego, a różnicujące wysokość świadczenia z uwagi na wiek osoby niepełnosprawnej. http://www.mpips.gov.pl/aktualnosci-wszystkie/ inne/art,7083,jedno-swiadczenie-dla-opiekunow-osob-niepelnosprawnych.html (dostęp: 1 marca 2014 r.). 
czenia, którego pochodną jest objęcie ubezpieczeniem, czy to do objęcia ubezpieczeniem przy spełnieniu kryterium dochodowego.

I tak, w art. 6 ust. 2 ustawy o systemie ubezpieczeń społecznych stanowi się, że zasady podlegania ubezpieczeniom emerytalnemu i rentowym osób rezygnujących z zatrudnienia w związku z koniecznością sprawowania bezpośredniej, osobistej opieki nad długotrwale lub ciężko chorym członkiem rodziny oraz wspólnie niezamieszkującymi matką, ojcem lub rodzeństwem, za które ośrodek pomocy społecznej opłaca składkę, regulują przepisy o pomocy społecznej. A w ust. 2a wskazuje się, że za osobę pobierającą świadczenie pielęgnacyjne, specjalny zasiłek opiekuńczy albo zasiłek dla opiekuna wójt, burmistrz lub prezydent miasta opłaca składkę (nie wiedzieć dlaczego nie: składki) na ubezpieczenia emerytalne i rentowe od podstawy w wysokości odpowiadającej wysokości odpowiednio świadczenia pielęgnacyjnego albo specjalnego zasiłku opiekuńczego przysługujących na podstawie przepisów o świadczeniach rodzinnych, zasiłku dla opiekuna przysługującego na podstawie przepisów o ustaleniu i wypłacie zasiłków dla opiekunów.

Poza ubezpieczeniem emerytalnym i rentowymi wskazani opiekunowie nie podlegają innym ubezpieczeniom społecznym. Przy czym w zakresie ubezpieczenia chorobowego brzmienie przepisu nie budzi wątpliwości. Wynika z niego wyraźnie, że wskazani opiekunowie nie podlegają ani obowiązkowo, ani dobrowolnie ubezpieczeniu chorobowemu. O tyle w przypadku ubezpieczenia wypadkowego art. 12 nie brzmi logicznie i należy zgłosić względem niego zastrzeżenia interpretacyjne. Wskazuje on bowiem, że ubezpieczeniu wypadkowemu podlegają osoby podlegające ubezpieczeniu emerytalnemu i rentowym z wyłączeniem bezrobotnych pobierających zasiłek dla bezrobotnych lub świadczenie integracyjne, posłów do Parlamentu Europejskiego, o których mowa w art. 1 ust. 1 ustawy z dnia 30 lipca 2004 r. o uposażeniu posłów do Parlamentu Europejskiego wybranych w RP, oraz osób o których mowa w art. 6 ust. 1 pkt 2, 11, 19-22, art. 6a i art. 7. Nie wyklucza zatem osób wskazanych art. 6 ust. 2 i ust. 2a. Można dowodzić, że art. 6 ust. 2 i ust. 2a nie zostały ujęte wśród przepisów wyłączających ubezpieczenie wypadkowe z tych powodów, iż art. 6 ust. 2 odwołuje się w zakresie ubezpieczenia społecznego do ustawy o pomocy społecznej. Stanowi, że zasady podlegania ubezpieczeniom emerytalnemu 
i rentowym osób rezygnujących z zatrudnienia w związku z koniecznością sprawowania bezpośredniej, osobistej opieki nad długotrwale lub ciężko chorym członkiem rodziny oraz wspólnie niezamieszkującymi matką, ojcem lub rodzeństwem, za które ośrodek pomocy społecznej opłaca składkę, regulują przepisy o pomocy społecznej. Z czego wnioskować by należało, że nie ustawa systemowa. A stąd brak potrzeby ujęcia tego przepisu wśród wyłączeń z ubezpieczenia wypadkowego, skoro o zasadach ubezpieczenia decyduje inna ustawa i nie przewiduje względem tych osób ubezpieczenia wypadkowego. Zaś art. 6 ust. 2a korzysta z innej figury stylistycznej i nie wskazuje, jak art. 6 ust. $1 \mathrm{w}$ zdaniu pierwszym, kto podlega ubezpieczeniom emerytalnemu i rentowym (a to osoby podlegające tym ubezpieczeniom obowiązkowo podlegają co do zasady wypadkowemu ze wskazanymi wyjątkami), tylko posługuje się sformułowaniem, iż za wskazane tym przepisem osoby składkę opłaca na ubezpieczenia emerytalne i rentowe odpowiedni organ administracji samorządowej. Jednak trudno jednoznacznie stwierdzić, czy to treść art. 6 ust. 2 i ust. 2a przesądziła o tym, iż w przesłankach ubezpieczenia wypadkowego ustawodawca w ogóle się do nich nie odniósł. Czy też jest to wynikiem pewnego przeoczenia. Bez wątpienia po przepisach stanowiących obowiązki publicznoprawne nie tylko dla obywateli, ale i dla organów administracji należałoby oczekiwać większej precyzji w ich stanowieniu.

Art. 6 ust. 2 obowiązuje od początku wejścia w życie ustawy systemowej. Pierwotnie przewidywał, że zasady podlegania ubezpieczeniom emerytalnemu i rentowym osób pobierających zasiłek stały lub gwarantowany zasiłek okresowy z pomocy społecznej regulują odrębne przepisy. Jak wskazuje ustawa w obecnym brzmieniu, zasady podlegania ubezpieczeniom emerytalnemu i rentowym osób rezygnujących z zatrudnienia w związku z koniecznością sprawowania bezpośredniej, osobistej opieki nad długotrwale lub ciężko chorym członkiem rodziny oraz wspólnie niezamieszkującymi matką, ojcem lub rodzeństwem, za które ośrodek pomocy społecznej opłaca składkę, regulują przepisy o pomocy społecznej. W ustawie o pomocy społecznej poddano je kazuistycznej regulacji ${ }^{8}$.

$8 \quad$ I. Sierpowska, Pomoc społeczna. Komentarz, Warszawa, LEX 2014 r., komentarz do art. 42. 
Zgodnie z art. 42 ust. 1 ustawy o pomocy społecznej za osobę, która zrezygnuje z zatrudnienia w związku z koniecznością sprawowania bezpośredniej, osobistej opieki nad długotrwale lub ciężko chorym członkiem rodziny oraz wspólnie niezamieszkującymi matką, ojcem ${ }^{9}$ lub rodzeństwem, ośrodek pomocy społecznej opłaca składkę na ubezpieczenia emerytalne i rentowe od kwoty kryterium dochodowego na osobę w rodzinie, jeżeli dochód na osobę w rodzinie osoby opiekującej się nie przekracza 150\% kwoty kryterium dochodowego na osobę w rodzinie i osoba opiekująca się nie podlega obowiązkowo ubezpieczeniom emerytalnemu i rentowym z innych tytułów lub nie otrzymuje emerytury albo renty. Dotyczy to również osób, które w związku z koniecznością sprawowania opieki pozostają na bezpłatnym urlopie. Konieczność sprawowania bezpośredniej, osobistej opieki nad osobami, o których mowa w art. 42 ust. 1, stwierdza lekarz ubezpieczenia zdrowotnego w zaświadczeniu wydanym nie wcześniej niż na 14 dni przed złożeniem wniosku o przyznanie świadczenia.

Opłacanie składek na ubezpieczenia emerytalne i rentowe na podstawie ustawy o pomocy społecznej należy do kategorii świadczeń niepieniężnych z pomocy społecznej i stanowi zadanie własne gminy o charakterze obowiązkowym. Pozwala ono na utrzymanie osób wymagających opieki w ich środowisku, jednocześnie stwarzając możliwość nabycia stażu ubezpieczeniowego ich niezamożnym opiekunom ${ }^{10}$. Ma status publicznego prawa podmiotowego, gdyż osobie spełniającej wymagania do przyznania tego świadczenia służy roszczenie do organów pomocy społecznej o jego przyznanie $^{11}$. Jednocześnie jest świadczeniem tego rodzaju, które nie podlega zleceniu przez organy administracji samorządowej (art. 25 ust. 2 pkt. 2).

Uprawnienie osoby rezygnującej z zatrudnienia do opłacania za nią składek ubezpieczeniowych nie wynika jednak bezpośrednio z mocy prawa. Świadczenie w postaci opłacania składek przyznawane jest na wniosek i przysługuje jedynie na przyszłość. Obowiązujące przepisy nie dają podstaw do przyznania świadczenia w postaci opłacania składek na ubez-

\footnotetext{
9 Przez ojca i matkę należy rozumieć również ojca i matkę współmałżonka.

10 I. Sierpowska Pomoc społeczna....

11 S. Nitecki, Prawo do pomocy społecznej w polskim systemie prawnym, Warszawa 2008, s. 207.
} 
pieczenie społeczne za okres przed złożeniem wniosku ${ }^{12}$. W dodatku uzależnione jest od spełnienia szeregu przesłanek, których wnikliwe zbadanie musi nastąpić w określonym postępowaniu, w którym przyznanie świadczenia w postaci opłacania składki na ubezpieczenie emerytalne i rentowe następuje na podstawie decyzji wydanej przez organ właściwy w sprawach z zakresu pomocy społecznej ${ }^{13}$. Takie stanowisko usuwa jednocześnie ewentualne wątpliwości, czy decyzji tej nie powinien wydać Zakład Ubezpieczeń Społecznych ${ }^{14}$.

Ustawa o pomocy społecznej wskazuje na wymóg rezygnacji z zatrudnienia, pomijając inną okoliczność, jaką jest niepodejmowanie zatrudnienia przez osobę, która przed objęciem opieki nie była aktywa zawodowo. Warunkiem przyznania świadczenia nie jest więc okoliczność niepodejmowania zatrudnienia z racji sprawowania opieki nad chorym członkiem rodziny, jak to zostało uregulowane w ustawie o świadczeniach rodzinnych. Ustawa o pomocy społecznej wymaga, aby między zakończeniem zatrudnienia a koniecznością opieki istniał związek przyczynowy, polegający na tym, że bez konieczności sprawowania bezpośredniej, osobistej opieki osoba zainteresowana nie zrezygnowałaby z zatrudnienia ${ }^{15}$. Ustawa nie definiuje przesłanki rezygnacji z zatrudnienia. Pomocne dla określenia przypadków rezygnacji z zatrudnienia uprawniających do świadczenia postaci opłacania składek jest zawarta w ustawie definicja zatrudnienia. I tak, za osobę zatrudnioną ustawa o pomocy społecznej traktuje osobę pozostającą w zatrudnieniu w rozumieniu przepisów o promocji zatrudnienia i instytucjach rynku pracy lub prowadzącą działalność gospodarczą w rozumieniu przepisów dotyczących działalności gospodarczej. Zatem osoba niepozostająca w zatrudnieniu to osoba niewykonująca pracy na podstawie stosunku pracy, stosunku służbowego oraz umowy o pracę nakładczą, a także osoba nieprowadząca pozarolniczej działalności gospodarczej. Chodzi zatem o tego rodzaju zatrudnienie, które zostało wyraźnie zdefiniowane w ustawie o pomocy społecznej. Poza zakresem zatrudnienia mieści się wykonywanie

Wyrok WSA z dnia 30 września 2010 r., IV SA/Gl 168/10, LEX 758318.

13 Uchwała NSA z dnia 16 września 2002 r. OPS 6/02, „Casus” 2003 nr 27, wkładka s. 1 przywoł. przez I. Sierpowska, Pomoc społeczna...

14 I. Sierpowska, Pomoc społeczna...

$15 \quad$ Tamże, komentarz do art. 42.
} 
pracy na podstawie umów cywilnoprawnych. Barierą w podejmowaniu jednak innego zatrudnienia, niewskazanego w ustawie o promocji zatrudnienia i instytucjach rynku pracy lub w przepisach dotyczących działalności gospodarczej jest nie tylko konieczność sprawowania bezpośredniej, osobistej opieki nad długotrwale lub ciężko chorym członkiem rodziny oraz wspólnie niezamieszkującymi matką, ojcem lub rodzeństwem, ale i konieczność wykazania dochodu, którego wysokość ma wpływ na przyszłe świadczenia w opłacaniu składek. Rezygnacja z zatrudnienia została również poddana ocenie sądów administracyjnych i NSA. W ich ocenie rezygnacja z zatrudnienia w celu sprawowania opieki nie może budzić wątpliwości. Musi to być stan trwały, czyli osoba taka musi zrezygnować definitywnie zarówno z aktualnego zatrudnienia, jak i nie podejmować tego zatrudnienia w przyszłości ${ }^{16}$. Między rezygnacją z pracy, a koniecznością sprawowania opieki nad osobami wymienionymi w tej normie musi istnieć ścisły związek ${ }^{17}$. I. Sierpowska dodatkowo przypomina, że w myśl komentowanej ustawy rodzinę tworzą zarówno osoby spokrewnione, jak i niespokrewnione, lecz - co istotne - pozostające w faktycznym związku, wspólnie zamieszkujące i gospodarujące. Nabycie uprawnienia do analizowanego świadczenia dopuszcza osobne zamieszkiwanie dla niektórych najbliższych krewnych wymagających opieki - matki, ojca i rodzeństwa oraz rodziców współmałżonka ${ }^{18}$.

Art. 6 ust. 2a został dodany w związku z pojawieniem się ustawy o świadczeniach rodzinnych i wprowadzeniem świadczenia pielęgnacyjnego. Ulegał on zmianom z uwagi na modyfikacje, jakie następowały w ramach świadczeń opiekuńczych. Przepisy przewidujące świadczenia

\footnotetext{
$16 \quad$ Wyrok NSA z dnia 17 maja 2010 r., I OSK 123/10, LEX nr 594975.

17 Wyrok WSA w Warszawie z dnia 19 listopada 2009 r., VIII SA/Wa 436/09, LEX nr 589566. Uprawnienie osoby rezygnującej z zatrudnienia do opłacania za nią składek ubezpieczeniowych nie wynika bezpośrednio z mocy prawa, ale uzależnione jest od spełnienia szeregu przesłanek, których wnikliwe zbadanie musi nastąpić w określonym postępowaniu, a rozstrzygnięcie mieć formę prawną decyzji administracyjnej. Między rezygnacją z pracy a koniecznością sprawowania opieki nad osobami wymienionymi w tej normie musi istnieć ścisły związek. Nie można zatem uznać, że dzierżawa gospodarstwa rolnego jest formą zatrudnienia i związku z tym spełnia przesłanki rezygnacji z tegoż zatrudnienia do przyznania mu żądanego świadczenia.

18 I Sierpowska, Pomoc społeczna...
} 
opiekuńcze na podstawie ustawy o świadczeniach rodzinnych skutkujące objęciem ubezpieczeniami społecznymi oraz zasiłek dla opiekunów, którzy utracili prawo do świadczenia pielęgnacyjnego z 1 lipca 2013 r. ${ }^{19}$ podobnie jak ustawa o pomocy społecznej również wiążą się z brakiem aktywności zawodowej w związku ze sprawowaniem opieki. Przy czym przepisy dotyczące świadczeń opiekuńczych wskazują zarówno na rezygnację, jak i na niepodejmowanie zatrudnienia. Dodatkowo, gdy o świadczenia ubiegają się rolnicy, małżonkowie rolników bądź domownicy, świadczenia te przysługują odpowiednio: rolnikom w przypadku zaprzestania prowadzenia przez nich gospodarstwa rolnego; małżonkom rolników lub domownikom w przypadku zaprzestania prowadzenia przez nich gospodarstwa rolnego albo wykonywania przez nich pracy w gospodarstwie rolnym ${ }^{20}$. Jest to zatem przesłanka szersza niż w ustawie o pomocy społecznej, umożliwiająca pozyskiwanie świadczenia opiekuńczego, a za nim statusu ubezpieczonego bez konieczności wykazywania, że podjęcie opieki wiąże się bezpośrednio z zaprzestaniem pracy zarobkowej.

Z punktu widzenia ubezpieczeń społecznych wyznaczenie uprawnionych do objęcia obowiązkowo ubezpieczeniami emerytalnym i rentowymi w tym wypadku jest nieco łatwiejsze, gdyż obowiązek ten jest pochodną przyznanych uprzednio świadczeń. Nie rozstrzyga jednak wszystkich wątpliwości czy trudności dla podmiotów zobowiązanych do opłacania składek, choćby w związku z limitem okresu, za który składki są opłacane, o czym jeszcze poniżej.

\section{Finansowanie i podstawa wymiaru składek}

Przechodząc do zasad finansowania składek na ubezpieczenia emerytalne i rentowe opiekunów, którzy tym ubezpieczeniom podlegają, zacząć należy od tego, że środki finansowe przeznaczone na ten cel pochodzą ze środ-

Ustawa z dnia 4 kwietnia 2014 r. o ustaleniu i wypłacie zasiłków dla opiekunów (Dz.U. poz. 567) odwołuje się do przesłanek wskazanych ustawą o świadczeniach rodzinnych według stanu prawnego na dzień 31 grudnia $2012 \mathrm{r}$.

20 Art. 17 b ustawy o świadczeniach rodzinnych i art. 3 o ustaleniu i wypłacie zasiłków dla opiekunów. 
ków publicznych, budżetu gminy czy budżetu państwa. Nie trafiają bezpośrednio do ubezpieczonych, lecz są przekazywane do organu rentowego za pośrednictwem ośrodka pomocy społecznej bądź wójta, burmistrza lub prezydenta miasta. Opłacanie składek na ubezpieczenia emerytalne i rentowe za osobę, która zrezygnuje z zatrudnienia w związku z koniecznością sprawowania bezpośredniej, osobistej opieki nad długotrwale lub ciężko chorym członkiem rodziny oraz wspólnie niezamieszkującymi matką, ojcem lub rodzeństwem, stanowi zadanie własne i zarazem obowiązkowe gminy. Składki finansują w całości ośrodki pomocy społecznej ze środków własnych gminy. Z kolei składki na ubezpieczenia emerytalne i rentowe osób pobierających świadczenie pielęgnacyjne, specjalny zasiłek opiekuńczy bądź zasiłek dla opiekuna finansuje w całości wójt, burmistrz lub prezydent miasta ze środków dotacji z budżetu państwa przyznanej na ten cel.

Podstawę wymiaru składek na ubezpieczenia emerytalne i rentowe osób rezygnujących z zatrudnienia w związku z koniecznością sprawowania bezpośredniej, osobistej opieki nad długotrwale lub ciężko chorym członkiem rodziny oraz wspólnie niezamieszkującymi matką, ojcem lub rodzeństwem stanowi kwota kryterium dochodowego na osobę w rodzinie ustalona według odrębnych przepisów (ustawy o pomocy społecznej), z zastrzeżeniem dotyczącym proporcjonalnego przeliczenia podstawy w przypadku objęcia ubezpieczeniem za część miesiąca (miesiąc objęcia i miesiąc ustania ubezpieczenia) ${ }^{21}$. Podstawę wymiaru składek na ubezpieczenia emerytalne i rentowe osób pobierających świadczenie pielęgnacyjne albo specjalny zasiłek opiekuńczy czy zasiłek dla opiekuna na podstawie przepisów o ustaleniu i wypłacie zasiłków dla opiekunów stanowi odpowiednio kwota świadczenia pielęgnacyjnego, specjalnego zasiłku opiekuńczego albo zasiłku dla opiekuna ${ }^{22}$.

Wskazane ustawą systemową tytuły do ubezpieczeń rodzą obowiązek ubezpieczenia opiekunów, jeśli nie podlegają oni temu obowiązkowi z innego tytułu. Obowiązek ubezpieczenia ma więc charakter subsydiarny. Ośrodek pomocy społecznej opłaca składki, o ile uprawniony opiekun nie

$21 \quad$ Art. 18 ust. 5 i ust. 9 ustawy z dnia 13 października 1998 r. o systemie ubezpieczeń społecznych (tekst jedn. Dz.U. z 2013 r., poz. 1442 ze zm.).

22 Art. 18 ust. 5a ustawy z dnia 13 października 1998 r. o systemie ubezpieczeń społecznych (tekst jedn. Dz.U. z 2013 r., poz. 1442 ze zm.). 
podlega obowiązkowo ubezpieczeniom emerytalnemu i rentowym z innych tytułów lub nie otrzymuje emerytury albo renty. Zaś wójt, burmistrz lub prezydent miasta nie opłaca składki na ubezpieczenia emerytalne i rentowe za osobę pobierającą świadczenie pielęgnacyjne, specjalny zasiłek opiekuńczy albo zasiłek dla opiekuna, jeżeli podlega ona obowiązkowi ubezpieczenia społecznego z innego tytułu na podstawie ustawy lub na podstawie odrębnych przepisów. Wójt, burmistrz lub prezydent miasta, jeżeli wypłaca osobie świadczenie pielęgnacyjne, specjalny zasiłek opiekuńczy albo zasiłek dla opiekuna, może wystąpić do ZUS o udzielenie informacji o przebiegu ubezpieczenia oraz za jaki okres za tę osobę powinien opłacać składkę na ubezpieczenia emerytalne i rentowe. W dziedzinie zabezpieczenia społecznego określono je mianem świadczenia pochodnego od świadczenia pielęgnacyjnego ${ }^{23}$.

Składka na ubezpieczenia emerytalne i rentowe opiekunów, o których mowa w art. 6 ust. 2 a ustawy systemowej, nie jest opłacana przez cały okres opieki. Przepis stanowi, że jest opłacana w wysokości określonej ustawą o systemie ubezpieczeń społecznych przez okres sprawowania opieki, nie dłużej jednak niż przez okres niezbędny do uzyskania 25-letniego okresu ubezpieczenia (składkowego i nieskładkowego ${ }^{24}$ ), z zastrzeżeniem art. 87 ust. 1b ustawy o emeryturach i rentach z Funduszu Ubezpieczeń Społecznych, zwanej dalej ustawą emerytalną ${ }^{25}$. Art. 42 ustawy o pomocy społecznej (do której odsyła art. 6 ust. 2 ustawy systemowej) również przewiduje sytuacje, w których składka na ubezpieczenia emerytalne i rentowe nie przysługuje. Wyłączeniu podlegają osoby, które w dniu złożenia wniosku o przyznanie świadczenia: ukończyły 50 lat i nie posiadają okresu ubezpieczenia (składkowego i nieskładkowego) wynoszącego co najmniej 10 lat albo posiadają już okres ubezpieczenia (składkowy i nieskładkowy) wynoszący 25 lat, z zastrzeżeniem wspomnianego art. 87 ust. 1b ustawy emerytalnej, odnoszącym się do sukcesywnego wzrostu łącznego okresu składko-

23 D. Dzienisiuk, Świadczenia z ubezpieczenia chorobowego. Świadczenia rodzinne po zmianach, Warszawa 2004, s. 148.

24 Przy ustalaniu okresu ubezpieczenia okresy nieskładkowe ustala się w wymiarze nieprzekraczającym jednej trzeciej udowodnionych.

25 Ustawa z dnia 17 grudnia 1998 r. o emeryturach i rentach z Funduszu Ubezpieczeń Społecznych (Dz.U. z 2014 r. poz. 1440). 
wego i nieskładkowego. Ograniczony okres opłacania składek w systemie zdefiniowanej składki wpływa wyraźnie na wysokość przyszłych świadczeń $^{26}$. Ustawodawca, mając to na uwadze, przewiduje gwarancje minimalnego świadczenia emerytalnego i rentowego po spełnieniu warunków z ustawy emerytalnej. Jednak w przypadku niskiej podstawy wymiaru składek przy obliczaniu w przyszłości okresów składkowych przypadających po dniu wejścia w życie ustawy dla celów podwyższenia emerytury do dolnej granicy wysokości emerytury obowiązuje zasada, że miesiące, w których składki na ubezpieczenia emerytalne i rentowe były obliczone od podstawy wymiaru niższej od kwoty minimalnego wynagrodzenia pracowników, uwzględnia się w części odpowiadającej proporcji tej podstawy do kwoty minimalnego wynagrodzenia. Wiadomo, że podstawę wymiaru składek od świadczeń przysługujących na podstawie ustawy o świadczeniach rodzinnych czy podstawę wymiaru składek opłacanych na podstawie ustawy o pomocy społecznej stanowi niższa kwota. Ustawodawca przewidział zatem, że wspomnianej zasady nie stosuje się m.in. wówczas, jeżeli podstawę wymiaru składek na ubezpieczenia emerytalne i rentowe stanowiła kwota zasiłku stałego z pomocy społecznej, świadczenia pielęgnacyjnego lub specjalnego zasiłku opiekuńczego określonych w przepisach o świadczeniach rodzinnych lub zasiłku dla opiekuna określonego w przepisach o ustaleniu i wypłacie zasiłków dla opiekunów (art. 87 ust. 3 ustawy emerytalnej). Nie odniósł się jednak do opiekunów, o których mowa w art. 42 ustawy o pomocy społecznej.

\section{Dobrowolne ubezpieczenia emerytalne i rentowe}

Sytuacje wskazane ustawą o pomocy społecznej, ustawą o świadczeniach rodzinnych i ustawą o ustaleniu i wypłacie zasiłków dla opiekunów nie wyczerpują wszystkich wypadków niepozostawania w zatrudnieniu z powodu opieki nad niepełnosprawną osobą. Będą to osoby nieobjęte zarówno

\footnotetext{
26 Na temat modeli finansowania ubezpieczeń społecznych zob. u J. Wantoch-Rekowski, Składki na ubezpieczenie emerytalne. Konstrukcja i charakter prawny, Toruń 2005, s. 22-27.
} 
świadczeniem pielęgnacyjnym i zasiłkiem dla opiekuna oraz osoby nieobjęte specjalnym zasiłkiem opiekuńczym lub nieobjęte ubezpieczeniem emerytalno-rentowym na podstawie art. 42 ustawy o pomocy społecznej, czyli osoby niespełniające przesłanek do uzyskania wspomnianych świadczeń i niespełniające kryterium dochodowego, o którym mowa w art. 42 ustawy o pomocy społecznej. Osoby takie mogą skorzystać z dobrowolnego ubezpieczenia emerytalno-rentowego na podstawie art. 7 ustawy emerytalnej. Przepis ten przewidywał taką możliwość już wcześniej, przed zmianą w 2012 r. ${ }^{27}$ Nie jest to jednak rozwiązanie docelowe dla tej grupy osób. Zwłaszcza z uwagi na zubożenie rodzin z osobą niepełnosprawną, nawet jeśli przekraczają one progi kryteriów dochodowych, tam gdzie uprawnienie do objęcia opiekunów obowiązkowo ubezpieczeniem jest z nimi związane (art. 42 o pomocy społecznej, specjalny zasiłek opiekuńczy). W przypadku dobrowolnego ubezpieczenia emerytalnego i rentowych należy zwrócić uwagę na art. 10 wskazujący, że jeżeli okres dobrowolnego objęcia ubezpieczeniami emerytalnym i rentowymi przekracza 10 lat, nie obowiązuje gwarancja wypłaty minimalnego świadczenia, w wypadku gdy stan własnego konta ubezpieczonego nie będzie go zapewniał.

\section{Odrębna podstawa prawna ubezpieczenia zdrowotnego opiekunów}

Na marginesie wskazać należy, że odrębne przepisy przewidują warunki objęcia opiekunów ubezpieczeniem zdrowotnym. Przewidują, że ubezpieczeniu zdrowotnemu podlegają spośród opiekunów rezygnujących z zatrudnienia osoby pobierające specjalny zasiłek opiekuńczy lub świadczenie

27 Art. 7 został zmieniony przez art. 6 pkt. 2 ustawy z dnia 11 maja 2012 r. o zmianie ustawy o emeryturach i rentach z Funduszu Ubezpieczeń Społecznych oraz niektórych innych ustaw (Dz.U., poz. 637). Wskazywała na to D. Dzienisiuk, Świadczenia z ubezpieczenia chorobowego. Świadczenia rodzinne po zmianach..., s. 148-149. I choć pogląd ten został wyrażony na gruncie art. 7 ust. ustawy systemowej w brzmieniu przed 1 stycznia 2013 r. to pozostaje on aktualny w tym sensie, iż nadal występują grupy opiekunów nieobjęte obowiązkowo ubezpieczeniami emerytalnym i rentowym, którym przysługiwać będzie prawo do podjęcia ubezpieczenia dobrowolnego. 
pielęgnacyjne, przyznane na podstawie przepisów o świadczeniach rodzinnych, niepodlegające obowiązkowi ubezpieczenia zdrowotnego z innego tytułu oraz osoby pobierające zasiłek dla opiekuna, przyznany na podstawie przepisów o ustaleniu i wypłacie zasiłków dla opiekunów, niepodlegające obowiązkowi ubezpieczenia zdrowotnego $\mathrm{z}$ innego tytułu. Istnieje potencjalnie również możliwość zgłoszenia wniosku o objęcie dobrowolnie ubezpieczeniem zdrowotnym osób nieobjętych nim obowiązkowo. Jednak podstawa wymiaru tego ubezpieczenia i konieczność poniesienia dodatkowo stosownej opłaty zależnej od okresu niepodlegania wcześniej ubezpieczeniu stanowi z pewnością istotna barierę dla tych opiekunów, którzy nie są objęci obowiązkowo ubezpieczeniem zdrowotnym ${ }^{28}$. Wreszcie nadmienić wypada, że na podstawie ustawy o pomocy społecznej osobom niemającym dochodu oraz możliwości uzyskania świadczeń na podstawie przepisów o świadczeniach opieki zdrowotnej finansowanych ze środków publicznych może być przyznany zasiłek celowy na pokrycie części lub całości wydatków na świadczenia zdrowotne.

\section{Podsumowanie}

Jak wynika z analizy omawianych tytułów do ubezpieczeń społecznych opiekunów, funkcjonują one w oparciu o różne przesłanki, niemające charakteru jednorodnego. Nie należą do ich wyłącznie samo sprawowanie opieki połączone z rezygnacją z aktywności zawodowej (przy braku innego tytułu), lecz sytuacja materialna rodziny czy pobieranie stosownego świadczenia zależnego od spełnienia dalszych, konkretnych przesłanek. Skomplikowany i niestabilny status ubezpieczeniowy opiekunów dodatkowo pogłębiają permanentne zmiany polityki państwa w systemie świadczeń opiekuńczych.

Ochrona ubezpieczeniowa opiekunów wydaje się pozostawać trwałym rozwiązaniem, choć wątpliwe jest, na ile opłacanie składek ze środków

\footnotetext{
28 Art. 68 ust. 7-11 ustawy z dnia 27 sierpnia 2004 r. o świadczeniach opieki zdrowotnej finansowanych ze środków publicznych, (tekst jedn. Dz.U. z 2008 r., Nr 164, poz. 1027 ze zm.).
} 
publicznych za osoby nieaktywne zawodowo pozostaje w zgodzie z koncepcją wspólnoty ryzyka jednorodnej grupy ubezpieczonych jako podstawy funkcjonowania ubezpieczeń społecznych ${ }^{29}$. Przy czym opiekunowie w zakresie ubezpieczenia emerytalno-rentowego nie są w tym względzie odosobnieni. A ostateczny kształt ich ochrony nie został jeszcze nakreślony. Będzie pochodną rozwiązań przyjętych dla opiekunów, które stanowią narastający problem społeczny.

\section{Bibliografia:}

Dzienisiuk D., Świadczenia z ubezpieczenia chorobowego. Świadczenia rodzinne po zmianach, Difin, Warszawa 2004.

Dzienisiuk D., Wpływ ubezpieczonych na prawo do świadczeń z tytułu rodzicielstwa, „Państwo i Prawo” 2013, nr 8 s. 36-51.

Gudowska B., Strusińska-Żukowska J., Ustawa o systemie ubezpieczeń społecznych. Komentarz, Beck, Warszawa 2014.

Nitecki S., Prawo do pomocy społecznej w polskim systemie prawnym, Wolters Kluwer, Warszawa 2008.

Sierpowska I., Pomoc społeczna. Komentarz, Warszawa, LEX 2014.

Wantoch-Rekowski J., Składki na ubezpieczenie emerytalne. Konstrukcja i charakter prawny, TNOiK, Toruń 2005.

29 W kontekście ubezpieczenia chorobowego zob. rozważania na ten temat u: D. Dzienisiuk, Wpływ ubezpieczonych na prawo do świadczeń z tytułu rodzicielstwa, „Państwo i Prawo" 2013, nr 8 s. 50. 